\title{
Membincang Homoseksualitas: Sikap Etis Kristiani Terhadap Pelaku Homoseksual
}

\author{
Firman Panjaitan \\ STT Tawangmangu \\ panjaitan.firman@gmail.com
}

\section{D0I: https://doi.org/10.34307/ b.v4i1.189}

\begin{abstract}
Homosexuality is often viewed as deviant and abnormal, and therefore it must be shunned and avoided. The act of staying away from homosexuality has an impact on homosexuals to be stigmatized as sinners and ultimately marginalized by the existing social system, including the church. There is an injustice felt by homosexuals. This issue is the main highlight in this article. By using a qualitative methodology, especially by studying various literatures as material for analysis and then responding to the problems set out in the form of a narrative, the writer tries to build a Christian-ethical attitude towards the perpetrators of homosexuality. The results of the study in this article reveal that ethically - Christians, the practice of homosexuality is an unacceptable act. So, what needs to be considered and rejected is the problem of homosexuality, but this is certainly different when it is faced with homosexuals. The homosexual perpetrators (people) are still human beings who have the same dignity as other humans, they are God's creations who have the right to live and be accepted into life in this world. Therefore, the ethical - Christian attitude of the church in responding to the existence of homosexuals is that they must have the courage to accept them as brothers because their existence as humans is the same, namely as "the image and likeness of God".
\end{abstract}

Keywords: church, ethical-christianity, homosexuality, homosexual offender

Abstrak: Homoseksualitas seringkali dipandang sebagai tindakan yang menyimpang dan abnormal, oleh sebab itu harus dijauhi dan dihindari. Tindakan menjauhi homoseksualitas berdampak kepada kaum homoseksual mendapat stigma kaum berdosa dan akhirnya dimarginalisasikan oleh sistem kemasyarakatan yang ada, termasuk gereja. Ada ketidakadilan yang dirasakan oleh kaum homoseksual. Masalah inilah yang menjadi sorotan utama dalam artikel ini. Dengan menggunakan metodologi kualitatif, khususnya dengan memelajari berbagai literatur sebagai bahan analisis kemudian menanggapi masalah yang dituangkan dalam bentuk narasi, penulis berusaha membangun sikap etis - Kristiani terhadap pelaku homoseksualitas. Hasil kajian dalam artikel ini mengungkapkan bahwa secara etis - Kristiani, praktik homoseksualitas adalah tindakan yang tidak bisa diterima. Jadi yang perlu untuk dipertimbangkan dan ditolak adalah masalah praktik homoseksualitas itu, namun hal ini tentu berbeda jika diperhadapkan dengan kaum homoseksual. Para pelaku (kaum) homoseksual tetaplah sebagai manusia yang memiliki harkat hidup sama dengan manusia lainnya, mereka adalah ciptaan Tuhan yang berhak untuk hidup dan diterima keberadaannya dalam kehidupan di dunia ini. Oleh sebab itu, sikap etis - Kristiani gereja dalam menyikapi keberadaan kaum homoseksual ini adalah harus berani menerima mereka sebagai seorang saudara karena keberadaan mereka sebagai manusia adalah sama, yaitu sebagai 'gambar dan rupa Allah'.

Kata kunci: etis-kristiani, gereja, homoseksualitas, pelaku homoseksual 


\begin{tabular}{llll}
\hline Article History : & Received: 09-07-2020 & Revised: 16-03-2021 & Accepted: 21-04-2021
\end{tabular}

\section{Pendahuluan}

Perbincangan tentang homoseksualitas, yang merupakan istilah untuk menunjuk pada orientasi seksual yang sejenis (lazimnya disebut Gay dan Lesbian) berasal dari dua kata, yaitu: homoos (satu; sama) dan seksual (hubungan kelamin) sehingga dapat didefinisikan homoseksual sebagai sexual desire or behavior directed toward a person of one's own sex, tetap aktual sepanjang kehidupan manusia, karena masalah ini menyangkut keberadaan diri manusia itu sendiri, khususnya berkaitan langsung dengan jenis kelamin (sex) manusia. ${ }^{1}$ Banyak pandangan yang kontra terhadap homoseksualitas, karena umumnya manusia hidup dalam pola hubungan heteroseksual (hubungan seksual beda jenis kelamin), yang notabene sudah menjadi 'peraturan umum' karena telah dilegalkan oleh lembaga agama yang dipandang sebagai lembaga paling kredibel tentang hubungan seksual. Setiap tindakan seksual yang berbeda dengan apa yang telah dilegalkan oleh lembaga agama, dipandang sebagai tindakan yang 'menyimpang' dan tidak dapat dibenarkan. Itulah sebabnya, secara legal-formal keagamaan, homoseksualitas merupakan bentuk penyimpangan seksual yang tidak dapat dibenarkan. Lebih lanjut, membincang homoseksualitas ternyata tidak berhenti sampai sikap pelarangan terhadap tindakan homoseksualitas, bahkan merambah terhadap pribadi si pelaku yang dipandang sebagai pribadi berdosa dan terkutuk, sehingga dalam kehidupan sehari-hari mereka mendapatkan perlakuan berbeda dan dikucilkan dari kegiatan bermasyarakat. Dalam hal ini bukan hanya homoseksualitas yang dilarang, melainkan juga menempatkan pelaku sebagai pesakitan yang dipandang tidak layak hidup berdampingan secara normal dengan masyarakat pada umumnya. Inilah masalah yang harus dikritisi secara etis Kristiani.

Perbincangan tentang homoseksualitas menjadi semakin tajam ketika, pada tahun 2016, Persekutuan Gereja-Gereja di Indonesia (PGI) mengeluarkan "Surat Pernyataan Sikap" dalam rangka menanggapi maraknya pemberitaan tentang LGBT (Lesbian, Gay, Biseksual dan Trans-Gender) yang dipandang sudah merambah masuk dengan deras ke Indonesia. ${ }^{2}$ Dalam surat tersebut, sebenarnya PGI menyadari bahwa masalah LGBT merupakan masalah yang perlu untuk disikapi dengan penuh kebijaksanaan dan masih harus terus dipergumulkan oleh setiap gereja di Indonesia; dengan tujuan agar gerejagereja di Indonesia memiliki sikap yang jelas terhadap masalah LGBT. Dalam pernyataan sikapnya PGI menyatakan bahwa, di satu sisi PGI menyadari kepelbagaian ajaran gereja dalam menyikap fenomena LGBT, namun di sisi lain dengan tegas PGI mengajak setiap

${ }^{1}$ John W. Drakeford, A Christian View of Homosexuality (Tennessee: Broadman Press, 1977), 31.

2 PGI, "Pengantar Penyataan Sikap PGI," No.: 360/PGI-XVI/2016 (Jakarta, June 17, 2016).ditandatangani oleh Majelis Pekerja Harian (MPH) PGI, yaitu: Pdt. Dr. Henriette T.H.-Labang (Ketua Umum) dan Pdt. Gomar Gultom (Sekretaris Umum) 
gereja mau mendalami persoalan tentang LGBT, agar Roh Tuhan akan menuntun gereja untuk bisa bersikap dengan bijaksana dalam menanggapi permasalahan tentang LGBT. ${ }^{3}$

Selanjutnya, secara implisit, MPH-PGI menjelaskan bahwa tindakan LGBT adalah tindakan yang tidak dapat dibenarkan karena tidak sesuai dengan apa yang menjadi prinsip dasar mengenai seksualitas dalam Alkitab; namun yang dipermasalahkan oleh PGI adalah sikap terhadap pelaku LGBT.4 PGI menjelaskan bahwa gereja perlu untuk menyusun sebuah bentuk pendampingan yang tepat terhadap setiap pelaku LGBT, sehingga nilai-nilai kemanusiaan yang ditumbuhkembangkan oleh gereja terhadap para pelaku LGBT tetap dikedepankan. Pelaku LGBT tetaplah seorang manusia yang merupakan 'gambar dan rupa Allah', sehingga mereka pun berhak untuk mendapatkan penghargaan terhadap kehidupan yang mereka jalani.

Namun penjelasan dalam surat Pernyataan Sikap PGI ini lebih banyak disalahpahami oleh berbagai denominasi gereja. Mereka menuduh PGI sebagai lembaga gereja yang berpihak kepada LGBT dan pada akhirnya mereka mulai mengeluarkan kecaman-kecaman terhadap keberadaan PGI. Bahkan ada beberapa gereja yang dengan sangat serius mengatakan bahwa mereka tidak mau berafilisasi dengan PGI karena mereka memandang bahwa PGI telah dipakai oleh 'kegelapan' untuk memberikan pengesahan terhadap tindakan yang jelas-jelas melawan Alkitab (Firman Allah). ${ }^{5}$ Penulis melihat ada pembiasan pemahaman yang dilakukan oleh gereja-gereja terhadap surat Pernyataan Sikap PGI ini. PGI berbicara tentang penghargaan terhadap nilai-nilai kemanusiaannya, meskipun saat itu mereka sedang berada dalam posisi sebagai pelaku LGBT; sedangkan tanggapan terhadap surat Pernyataan Sikap ini adalah menyoroti tentang sikap PGI yang 'seolah-olah' berpihak dan mengijinkan terjadinya praktik LGBT. Jelas hal ini tidak kena-mengena sama sekali.

Dengan menyadari adanya kesalahpahaman tersebut, maka tulisan ini akan memaparkan pandangan yang hendak mengembangkan sikap etis Kristiani terhadap pelaku homoseksualitas. Tulisan ini tidak secara khusus menyoroti tentang apakah homoseksualitas itu benar atau salah, karena bagian ini hanya diungkap di bagian awal, melainkan hendak menjabarkan bagaimana tindakan etis Kristiani terhadap pelaku homoseksualitas (Lesbian dan Gay).

${ }^{3}$ Ibid.

${ }^{4}$ Ibid., Lih. Bagian 'Titik Tolak' dan 'Rekomendasi' dari surat Pernyataan Sikap PGI terhadap LGBT.

${ }^{5}$ Dalam diskusi antar gereja, penulis mendengar sendiri beberapa wakil gereja mengatakan bahwa PGI berpihak pada LGBT, tetapi pada prinsipnya - sebenarnya - mereka sendiri belum pernah membaca surat Pernyataan Sikap PGI tersebut. Mereka lebih banyak mendengar berita-berita yang sejak awal memang sudah tidak memihak PGI (tidak obyektif). 


\section{Metode Penelitian}

Penelitian ini menggunakan pendekatan kualitatif di mana penulis akan berusaha mendeskripsikan suatu obyek, fenomena atau setting sosial yang dituangkan dalam tulisan yang bersifat naratif. ${ }^{6}$ Adapun metode yang digunakan adalah studi literatur di mana penulis berusaha mengumpulkan data dari sumber-sumber literatur yang berkorelasi dengan masalah penelitian. Selanjutnya analisis data dilakukan dengan memaparkan obyek yang diteliti lalu disajikan dalam bentuk uraian narasi. Data diperoleh dari berbagai sumber literatur, yaitu buku-buku dan artikel dari berbagai jurnal yang sesuai dengan fokus penelitian. Tujuan utama dari penggunaan metode literature research ini adalah mengembangkan sebuah pandangan kritis terhadap penelitian terdahulu dan mengembangkan sebuah perspektif baru dalam memahami topik penelitian yang dibahas, ${ }^{7}$ dalam hal ini adalah homoseksualitas.

\section{Hasil dan Pembahasan}

\section{Seks Di dalam Alkitab}

Sebelum mengurai pendapat penulis mengenai sikap etis Kristiani terhadap pelaku homoseksualitas, terlebih dahulu penulis menjelaskan pandangan Alkitab mengenai seksualitas, dengan tujuan agar pembaca mengetahui apa yang menjadi sikap dasar Alkitab terhadap masalah seksualitas. Secara umum dipahami bahwa istilah 'seks' menunjuk pada keadaan anatomis dan biologis, yaitu male (jenis kelamin jantan) atau female (jenis kelamin betina), di mana istilah 'jantan-betina' lebih menunjukkan aspek biologis. Istilah Jantan sering kali dipakai untuk manusia dalam istilah 'kejantanan', tetapi ekuivalen femininnya yaitu betina tidak pernah dipakai untuk manusia; namun dalam bahasa Inggris, betina adalah female yang selalu digunakan untuk merujuk pada jenis kelamin perempuan. ${ }^{8}$ dengan demikian ketika seseorang dilahirkan ia akan memiliki jenis kelamin tertentu seperti halnya memiliki ciri fisik lainnya yang berbeda dengan orang lain. Pemahaman 'seks' ini berbeda dengan 'seksualitas', di mana pengertian seksualitas mencakup seluruh kompleksitas emosi, perasaan, kepribadian, dan sikap atau watak sosial, berkaitan dengan identitas, prilaku atau orientasi seksual. Dalam istilah seksualitas terkandung pengertian sekaligus mengenai: dorongan seksual, yaitu dorongan manusia yang spesifik, yang dimiliki oleh setiap individu untuk tertarik pada lawan jenisnya; dan kehidupan (etis) seksual, yaitu dorongan seksual yang dimiliki oleh manusia yang diwujudkan dalam penerimaan dan penghayatan terhadap masalah-masalah seksual

${ }^{6}$ Albi Anggito and Johan Setiawan, Metodologi Penelitian Kualitatif (Sukabumi: CV Jejak, 2018), 11.

7 Fadlil Munawwar Manshur, "Teori Dialogisme Bakhtin Dan Konsep-Konsep Metodologisnya," SASDAYA: Gadjah Mada Journal of Humanities 1, no. 2 (2017).

8 Farsijana Adeney-Risakotta, "Menguak Teologi Feminis Asia," Gema Teologika 55 (1995): 1-23. 
(hubungan seks dan pemenuhan kebutuhan seksual) yang dikaitkan dengan normanorma kehidupan. ${ }^{9}$

Ernest Clinton Gardner, seorang ahli etika Kristen, mengatakan bahwa sikap etis Kristiani terhadap masalah seksualitas dapat ditumbuhkembangkan secara bertanggung jawab jika terlebih dahulu memahami adanya dua sikap ekstrim (dua cara pandang yang salah) terhadap seksualitas, yaitu Permisivisme Seksual dan Asketisme Seksual. Memahami dua sikap ekstrim ini diperlukan, karena sikap yang bertanggung jawab terhadap seksualitas letaknya ada di tengah-tengah, di antara kedua sikap ekstrim tersebut. Permisivisme Seksual adalah aliran yang menganjurkan kebebasan yang seluas-luasnya terhadap kehidupan seksual. Aliran ini memandang bahwa masalah seksual adalah melulu masalah fisiologis (jasmaniah), sehingga seks yang dimiliki oleh manusia sama sekali tidak dihargai. Pemenuhan kebutuhan seks harus segera dituntaskan jika memang diperlukan, dan hal ini tidak ada kait-mengaitnya dengan masalah moral. Setiap petunjuk atas larangan yang hendak membatasi aktivitas seksual, meskipun diatasnamakan norma (etika) dipandang sebagai hal yang mengungkung dan mengekang kebahagiaan manusia, dan hal ini bisa dinafikan. Kebalikan dari pandangan ini adalah Asketisme Seksual, yang mengatasnamakan dirinya sebagai sikap moral yang mengajak manusia untuk menjauhkan diri dari seksualitas. Aliran ini memandang bahwa hakikat seksualitas adalah salah dan jahat. Seksualitas dipandang identik dengan dosa dan ketidaksucian. Aliran ini memandang bahwa hidup yang berkenan di hadapan Tuhan adalah menjauhi seksualitas, bahkan kalau perlu hidup selibat dan mengabaikan seksualitas. Bagi aliran ini seks adalah tabu, sehingga aliran ini dikatakan sebagai aliran yang anti-seksualitas. ${ }^{10}$

Kedua pandangan ekstrim di atas merupakan produk dari cara pandang yang salah mengenai masalah seksualitas, karena pada akhirnya kedua cara pandang di atas sama sekali tidak menempatkan masalah seksualitas pada tempatnya yang semestinya. Hakikat seksualitas yang sesungguhnya hanya dapat dipahami melalui apa yang dijelaskan secara rinci oleh Alkitab. Berikut penulis akan menghadirkan hakikat seksualitas menurut Alkitab, yang merupakan kebenaran akan Firman Allah.

Dalam Kejadian 1: 26-27 digambarkan bahwa Allah menciptakan manusia sesuai dengan 'gambar dan rupa Allah'. Yang dimaksud dengan "sesuai” di sini adalah menunjuk pada keberadaan manusia sebagai seorang laki-laki dan perempuan (Ibr.: zakar dan neqevah - kedua kata Ibrani ini menunjuk pada jenis kelamin manusia). Jadi manusia dikatakan sesuai dengan gambar dan rupa Allah dalam kedudukan dan posisi seksualnya sebagai seorang laki-laki dan perempuan, sehingga kepada mereka (manusia laki-laki dan

\footnotetext{
${ }^{9}$ E.C. Gardner, Justice and Christian Ethics (Cambridge: Cambridge University Press, 1995); Firman Panjaitan, "Kekerasan Terhadap Istri Dalam Lingkup Domestik (Suatu Tinjauan Etis Kristiani Tentang Kekerasan Terhadap Keluarga)," Fidei: Jurnal Teologi Sistematika dan Praktika 1, no. 1 (2018): 42-67.

${ }^{10}$ Gardner, Justice and Christian Ethics; Tulus Tu'u, Etika Dan Pendidikan Seksual (Bandung: Kalam Hidup, n.d.).
} 
perempuan) Allah memberikan nilai-nilai utama dalam kehidupan yaitu spiritualitas dan hubungan yang tidak terpisahkan dengan Allah. Bahkan manusia pun dikatakan sebagai wujud representasi (kehadiran) Allah secara langsung di dunia. ${ }^{11}$ Dengan melihat kesesuaian gambar Allah dalam diri manusia melalui jenis kelamin, maka dapat dikatakan bahwa kekudusan manusia yang diwariskan oleh Allah terletak pada jenis kelamin yang mereka miliki. Laki-laki dikatakan kudus apabila ia dapat menjaga kekudusan kelaminnya (virginitas di dalam zakar), demikian juga perempuan akan dikatakan kudus ketika ia menjaga kekudusan kelaminnya (virginitas di dalam neqevah). ${ }^{12}$ Ketika Allah menjadikan manusia sebagai seorang laki-laki dan perempuan, sudah jelas Allah menciptakan jenis kelamin yang berbeda bagi keduanya, namun keduanya tetap dinamakan dengan nama yang sama yaitu manusia. Dengan demikian perbedaan antara laki-laki dan perempuan hanyalah terletak pada jenis kelamin, bukan pada penamaan diri sebagai manusia ataupun pada derajat kehidupan manusia. ${ }^{13}$ Karena keduanya memiliki penamaan diri yang sama, yaitu manusia. Dalam perbedaan jenis kelamin tersebut, Allah menganugerahkan manusia kemampuan untuk bereproduksi secara seksual yang ditunjukkan dengan ungkapan, "beranak cuculah dan bertambah banyak agar memenuhi bumi dan berkuasa atasnya." (Kejadian 1:28). Ini berarti bahwa seks dalam pernikahan adalah anjuran langsung dari Allah kepada manusia untuk memenuhi maksud dan rencana Allah bagi dunia ini. ${ }^{14}$ Dengan demikian kitab Kejadian menempatkan masalah seksualitas (jenis kelamin dan dorongan seksual) sebagai hal kudus, yang telah dianugerahkan Allah kepada manusia. ${ }^{15}$

Masalah kekudusan ini ditegaskan kembali oleh Rasul Paulus. Dalam 1 Timotius 4:4-5, Paulus menegaskan, "Karena semua yang diciptakan Allah itu baik dan satu pun tak ada yang haram, jika diterima dengan ucapan syukur, sebab semua itu dikuduskan oleh firman Allah dan oleh doa". Ungkapan ini mengartikan berarti setiap anugerah Allah harus diterima dengan penuh rasa syukur dan oleh iman kepada Allah. Manusia harus menghargai dan menghormati anugerah Allah. Karena seks adalah anugerah Allah, maka manusia jangan pernah meremehkan seks agar tidak mengakibatkan kerusakan jasmani dan rohani. ${ }^{16}$ Seks adalah bagian dari tubuh dan Allah menghendaki agar manusia menjaga tubuh dari segala bentuk kecemaran dan dosa, karena melalui tubuh itu Allah dimuliakan (I Kor. 6:19-20). Tubuh, yang adalah Bait Allah, harus dipelihara dalam

${ }^{11}$ Claus Westermann, Genesis 1-11: A Commentary (Minneapolis: London and Ausburg Publishing House, 1984), 148-150.

12 Ibid., 153.

${ }^{13}$ Junius Halawa, "Seks Menurut Alkitab Sebagai Kontribusi Bagi Pengajaran Gereja Masa Kini," Scripta: Jurnal Teologi dan Pelayanan Kontekstual 8, no. 2 (2020): 164-180.

14 Panjaitan, "Kekerasan Terhadap Istri Dalam Lingkup Domestik (Suatu Tinjauan Etis Kristiani Tentang Kekerasan Terhadap Keluarga)"; Tim Beverly Lahaye, Kehidupan Seks Dalam Pernikahan (Bandung: Kalam Hidup dan ANDRI, 1992).

${ }_{15}$ Yushiko D. Monding, "Tinjauan Teologis Tentang Pendidikan Seks Dari Perspektif Pendidikan Kristiani Transformatif," Pengarah: Jurnal Teologi Kristen 2, no. 2 (2020): 173-182.

${ }^{16}$ Tu'u, Etika Dan Pendidikan Seksual, 13. 
kekudusan sebab Allah hanya berkenan tinggal di dalam tempat yang kudus. Jika tubuh tidak boleh dicemarkan atau dirusak, maka seks (jenis kelamin) yang adalah bagian dari tubuh, juga tidak boleh dicemarkan atau dirusak. Merusak seks adalah sama dengan merusak Bait Allah dan sekaligus merusak kekudusan dari gambar dan rupa Allah.

\section{Diskursus Tentang Homoseksualitas}

Dalam bagian ini, penulis akan berusaha mengurai pemahaman tentang homoseksualitas dari segi sosiologis, psikologis maupun teologis agar lebih luas dan komprehensif, sehingga upaya membangun sikap etis Kristiani terhadap pelaku homoseksualitas tidak berat sebelah.

\section{Homoseksualitas dalam Pandangan Sosiologis dan Psikologis}

Secara umum seorang homoseks dapat didefinisikan sebagai orang yang memiliki orientasi/pilihan seksual dasarnya diarahkan kepada sesama jenis kelaminnya, baik itu diwujudkan atau dilakukan atau tidak. ${ }^{17}$ Homoseksualitas tidak hanya menyangkut hubungan antara laki-laki dengan laki-laki, melainkan juga hubungan antara perempuan dengan perempuan. Ada istilah gay yang digunakan untuk mengacu pada orang-orang yang mengidentifikasi dirinya sebagai homoseks, tanpa memandang jenis kelamin, sedangkan istilah lesbian lebih digunakan untuk merujuk kepada wanita homoseks.18 Penggunaan istilah homoseksual pertama kali dicatat dalam sejarah pada tahun 1869 dalam bidang ilmu psikiatri di Eropa, oleh Karl-Maria Kertbeny, Istilah ini dipakai untuk mengacu pada fenomena psikoseksual yang berkonotasi klinis. ${ }^{19}$ Banyak penelitian yang dilakukan untuk menjawab pertanyaan tentang apa yang menyebabkan orientasi atau praktik homoseksual; apakah gejala alami ataukah hasil konstruksi sosial/budaya. Jeffrey Satinover berpendapat bahwa penyebab homoseksualitas bukanlah eksklusif biologis atau psikologis, tetapi lebih pada hasil percampuran dari faktor genetik, pengaruh dalam kandungan (intrauterine), lingkungan setelah kelahiran (seperti keluarga dan perilaku budaya), dan rangkaian kompleksitas dari pilihan-pilihan yang diperkuat secara berulang-ulang yang terjadi pada fase kritis dari perkembangan. ${ }^{20}$

Berdasarkan hasil penelitian terhadap orientasi homoseksual, setidaknya ada empat faktor penyebabnya, yaitu: Pertama, faktor biologis, berupa: (a) Ketidakseimbangan hormon. Secara biologis pria tidak hanya memiliki hormon testoteron (yang diwarisi dari kromosom ayah), tetapi sekaligus memiliki hormon estrogen dan progesteron (yang diwarisi dari kromosom ibu) dalam kadar yang sangat sedikit. Jika kadar hormon esterogen dan progesteron dalam tubuh pria cukup tinggi, maka

17 Dede Oetomo, Memberi Suara Pada Yang Bisu (Yogyakarta: Pustaka Marwa, 2003), 6.

18 Yogestri Rakhmahappin and Adhyatman Prabowo, "Kecemasan Sosial Kaum Homoseksual Gay

Dan Lesbian," Jurnal Ilmiah Psikologi terapan 02, no. 02 (2014): 199-213.

${ }^{19}$ Oetomo, Memberi Suara Pada Yang Bisu, 7.

${ }^{20}$ Jeffrey Satinover, Homosexuality and the Politics of Truth (MI: Baker Books, 1996). 
perkembangan seksual seorang pria mendekati karakteristik wanita. Ini yang mengakibatkan mengapa seorang pria terlihat feminin dan memiliki perasaan yang lebih sensitif. Hal yang sama juga berlaku sebaliknya dengan seorang wanita. ${ }^{21}$ (b) Struktur otak yang ada pada straight females dan males dengan gay females dan gay males memiliki perbedaan. Otak bagian kanan dan kiri dari straight males terpisah dan dibatasi membran yang cukup tegas dan tebal sedangkan, otak antara bagian kanan dan kiri straight females tidak tegas dan tebal. Gay males memiliki struktur otak yang sama dengan straight females, dan pada gay females struktur otaknya sama dengan straight males. Salah satu sumbangan ilmiah yang terkenal dalam perdebatan ini yaitu temuan Dr. Simon Levay, tahun 1991. Ketika Levay memelajari otak 41 pria meninggal dan 19 di antaranya adalah homoseksual, ditemukan bahwa kelenjar hipotalamus (bagian dari otak yang terdiri dari sejumlah nukleus dengan berbagai fungsi yang sangat peka terhadap steroid, glukosa, dan suhu di mana salah satu fungsinya adalah memelihara tekanan darah, denyut jantung, suhu tubuh, perilaku konsumsi, dan emosi dan merupakan konektor sinyal ke berbagai bagian otak menuju korteks otak besar dan berfungsi sebagai monitoring serta mengontrol berbagai aktivitas dari tubuh yang sangat banyak, yang mengatur seksualitas seseorang) seorang homoseksual berbeda dengan heteroseksual. ${ }^{22}$ (c) Kelainan susunan syaraf akibat radang atau patah tulang dasar tengkorak otak, dapat memengaruhi perilaku seks heteroseksual maupun homoseksual.

Kedua, faktor psikodinamika, yaitu gangguan perkembangan psikoseksual pada masa kecil dan bentukan-bentukan dari keluarga. ${ }^{23}$ Ketiga, faktor sosiokultural, yaitu mengenai kebiasaan budaya setempat. ${ }^{24}$ Keempat, Faktor lingkungan, yang menyebabkan terjadi hubungan homoseksual. ${ }^{25}$

Homoseksualitas sebagai sesuatu yang genetis atau alamiah atau dikonstruksikan secara sosial ini telah menjadi perdebatan yang panjang dari banyak ahli, baik ahli biologi, seksolog, sosiolog, psikiater, maupun psikolog. Hasil studi Dr. Evelyn Hooker membuktikan bahwa homoseksualitas bukanlah sebuah penyakit atau perilaku menyimpang yang harus disembuhkan, seperti pendapat kebanyakan orang heteroseksual yang menganggap dirinya normal dan yang homoseksual tidak normal. Hooker, yang menguji kelompok-kelompok heteroseksual dan homoseksual,

${ }^{21}$ Malcolm MacCulloch, "Biological Aspects of Homosexuality," Journal of Medical Ethics (1980); Oetomo, Memberi Suara Pada Yang Bisu, 133-138;92-95.

22 Simon LeVay, In Queer Science (Cambridge: MIT Press, 1996), 19.

${ }^{23}$ Sandor Rado dan Bieber (1961), berpendapat bahwa homoseksual diakibatkan oleh pengalaman individu bersama kedua orangtuanya, yang dimulai sejak masa oedipal period (usia 4-5 tahun). Charles Socarides (1968) menambahkan bahwa perkembangan homoseksual individu dimulai sejak masa preoedipal dan sesudahnya, lih. "NN," “Facts About Homosexuality and Mental Health," accessed June 25, 2020, http://psychology.ucdavis.edu/rainbow/html/ facts_mental_health.htm; Uwe Hartmann, "Sigmund Freud and His Impact on Our Understanding of Male Sexual Dysfunction," Journal of Sexual Medicine 6, no. 8 (2009): 2332-2339.

${ }^{24}$ Oetomo, Memberi Suara Pada Yang Bisu, 34-35, 50, 100.

${ }^{25}$ Alfred Kinsey, Sexual Behaviour in the Human Female (Philadelphia: W. B. Saunders Co., 1953); 470 Oetomo, Memberi Suara Pada Yang Bisu120. 
mengungkapkan bahwa tidak ada perbedaan antara kedua kelompok ini dalam hal kemampuan fungsional, stabilitas, dan kreativitas. Penelitian Hooker mendorong Himpunan Psikiatri Amerika, tahun 1971, untuk mengeluarkan homoseksualitas dari daftar gangguan jiwa. ${ }^{26}$

Homoseksual dipandang sebagai perilaku seksual menyimpang karena seksualitas sering dimengerti dalam arti yang sempit, yang hanya terbatas pada alat genital, yaitu apa yang dialami dan dilakukan dengan alat kelamin. Perilaku homoseksual yang tertarik pada sesama jenis dianggap menyimpang berdasarkan pandangan terhadap seksualitas dalam arti sempit ini, bahwa orang yang menyukai sesama jenis tidak dapat melakukan hubungan alat kelamin seperti halnya hubungan antara pria dan wanita. Padahal sebenarnya seksualitas mempunyai arti yang sangat luas dan mendalam.

Pembahasan tentang homoseksualitas tidak dapat dilepaskan dari pembahasan mengenai seksualitas, sebab hal inilah yang menyebabkan terjadinya diskriminasi terhadap kaum homoseksual. Padahal Dewan Hak Asasi Manusia Perserikatan BangsaBangsa (Dewan HAM PBB) telah mengeluarkan resolusi yang menyatakan tidak boleh ada diskriminasi atau kekerasan terhadap orang berdasarkan orientasi seksualnya. Orangorang homoseksual, seperti halnya heteroseksual, memiliki hak untuk memilih siapa yang dicintai, dan menghabiskan hidup dengan mereka yang dicintai. ${ }^{27}$ Seksualitas yang dimaksud di sini memiliki makna yang luas, menyangkut seluruh aspek kehidupan yang meliputi konsep tentang seks (jenis kelamin), orientasi seksual, gender, erotisme, keintiman, kesenangan, dan reproduksi. Seksualitas dapat dialami dan diekspresikan dalam fantasi, hasrat, pikiran bahkan tingkah laku, kebiasaan, namun tidak semua aspek dalam seksualitas harus selalu diwujudnyatakan. Seksualitas sangat dipengaruhi oleh interaksi faktor-faktor agama, psikologis, biologis, ekonomi, sosial, politik, sejarah, dan spiritual.

Pada dasarnya, ada dua pandangan tentang seksualitas yang saling berseberangan. Pandangan pertama diwakili oleh kelompok Esensialisme, yang meyakini bahwa jenis kelamin, orientasi, dan identitas seksual adalah berupa gift dan bersifat natural sehingga tidak dapat mengalami perubahan. Jenis kelamin manusia hanya terdiri dari perempuan dan laki-laki; orientasi seksual hanya bersifat heteroseksual, dan identitas gender harus selaras dengan jenis kelamin (perempuan: feminin; laki-laki: maskulin). Setiap orang yang berada di luar keadaan ini dipandang abnormal. Pandangan kedua diwakili oleh kelompok Konstruksi Sosial (Social Constructionism) yang berpandangan bahwa konstruksi sosial akan menghasilkan pemahaman tentang seks/jenis kelamin, orientasi seksual, gender maupun identitas gender. Sebagai konstruksi sosial, maka seksualitas

${ }^{26}$ Oetomo, Memberi Suara Pada Yang Bisu, 150-151.

27 "NN," "UN Passes LGBT Rights Resolution," accessed July 1, 2020, http://en.wikinews.org/wiki/UN_passes_LGBT_rights_resolution?utm_source=feedburner\&um_ medium=feed\&utm_campaign=Feed\%3A+WikinewsLatestNews+\%28Wikinews+Latest+News\%29. 
manusia bersifat cair sehingga jenis kelamin manusia tidak hanya terdiri dari laki-laki dan perempuan saja, namun termasuk di dalamnya adalah intersex dan transgender/transeksual. Orientasi seksual pun tidak hanya heteroseksual namun termasuk juga homoseksual dan biseksual. Dengan demikian seksualitas adalah cermin untuk melihat keberadaan lembaga-lembaga sosial dalam masyarakat, seperti sistem nilai, agama, adat, negara serta kekuasaan. ${ }^{28}$ Konsepsi seksualitas selalu dibentuk oleh sistem kekeluargaan, perubahan sosial dan ekonomi, berbagai bentuk pengaturan sosial yang berubah, momen politik dan gerakan-gerakan perlawanan. ${ }^{29}$ Jadi, seksualitas mempunyai keterikatan yang erat dengan persoalan kekuasan, dan bukan sekadar perwujudan dari sistem nilai yang normatif dan abstrak. ${ }^{30}$

Foucault, sebagaimana yang dikutip oleh Suryakusuma, berpendapat bahwa aparatus seksualitas memiliki peran sentral dalam hal kekuasaan. Oleh karena itu kekuasaan terbentuk dari hubungan antara yang menciptakan dan yang menunjangnya. Dalam kekuasaan ada pengetahuan yang digunakan untuk mengontrol segala sesuatu. Dengan demikian setiap manusia, termasuk seksualitasnya, senantiasa ada dan diatur oleh kekuasaan. ${ }^{31}$ Selain itu, seksualitas seringkali dibebani dengan hal-hal yang berlebihan, misalnya ketika masalah sosial, politis dan ekonomi menimbulkan kepanikan moral maka yang seringkali dijadikan kambing hitam untuk masalah moralitas ini adalah perilaku seksual. Namun setiap masyarakat memiliki bentuk dan pola pemahaman yang berbeda mengenai seksualitas, sehingga konstruksi pandangan terhadap homoseksualitas mengalami perubahan dalam setiap masa. Akibatnya pandangan tentang homoseksual sebagai bentuk ganngguan kejiwaan dan perilaku abnormal dinafikan dan digantikan sebagai bentuk orientasi seksual.

Dalam konteks Indonesia, homoseksualitas sebagai konstruksi sosial mengalami pergeseran dalam hal penerimaan. Di abad 18-19, dalam beberapa tradisi budaya Nusantara (seperti di Aceh, Ponorogo, Dayak Ngaju dan Makassar dan Toraja) perilaku homoseksual diakui, diterima bahkan dilembagakan. ${ }^{32}$ Seiring dengan perkembangan keagamaan, penerimaan ini berubah menjadi penolakan bahkan pengharaman. Namun budaya toleransi bagi homoseks masih dipraktikkan, khususnya di kalangan kelas pekerja bawah yang belum banyak terkena dampak modernisasi, meski dapat dikatakan bahwa toleransi yang tampak itu dikarenakan ketidaktahuan mengenai homoseksualitas. Menurut Oetomo, sikap masyarakat Indonesia dapat dibagi menjadi dua, yaitu sikap pada peringkat kognitif-intelektual, di mana masih banyak orang Indonesia modern yang terpelajar merasa sulit untuk menerima homoseksualitas dan orang homoseks; dan

\footnotetext{
${ }^{28}$ Julia I. Suryakusuma, “Konstruksi Sosial Seksualitas,” Prisma 20, no. 7 (1991): 3.

${ }^{29}$ Jeffrey Weeks, "Question of Identity," in The Cultural Construction of Sexuality, ed. Pat Caplan (New York: Tavistock Publication, 1987), 12-15.

${ }^{30}$ Onghokham, "Kekuasaan Dan Seksualitas: Lintas Sejarah Pra Dan Masa Kolonial," Prisma 20, no. 7 (1991): 15-23.

31 Suryakusuma, "Konstruksi Sosial Seksualitas," 2.

32 Oetomo, Memberi Suara Pada Yang Bisu, 34-35, 50, 100.
} 
afektif-perilaku, dimana adanya toleransi dalam dunia show-biz, designing, dan salon. ${ }^{33}$ Memang secara informal-realitas, perilaku homoseksual masih diakui dan diterima, namun akibat hal itu dipandang menyimpang keluar dari ajaran agama, maka secara formal-rasional masyarakat masih belum menerima adanya perilaku homoseksual tersebut. Jadi masyarakat menilai perilaku homoseksual ini secara ambigu; di satu sisi, secara agama, medis, hukum dan opini publik, perilaku homoseksual dipandang dosa, tabu, jahat dan menyimpang dari norma, tetapi di sisi lain, dari segi budaya, masyarakat masih bisa menolerir perilaku homoseksual ini. ${ }^{34}$

Rangkaian pendapat di atas, baik secara sosiologis maupun psikologis, menegaskan bahwa homoseksualitas tidak lagi dikategorikan sebagai gangguan jiwa atau penyimpangan seksual. Jika homoseksualitas tetap dipandang sebagai bentuk penyimpangan orientasi seksual, maka pandangan ini akan memunculkan dampak negatif berupa stigmatisasi dan pengucilan oleh masyarakat. Hal inilah yang mendorong Organisasi Kesehatan Dunia (WHO) memutuskan untuk menghapus paham homoseksualitas sebagai bentuk dari gangguan kejiwaan, pada tanggal 17 Mei 1990, Keputusan WHO ini dicantumkan juga oleh Depkes RI dalam buku Pedoman Penggolongan dan Diagnosis Gangguan Jiwa di Indonesia edisi II tahun 1983 (PPDGJ II) dan PPDGJ III (1993). ${ }^{35}$ Dengan demikian homoseksualitas, biseksualitas maupun heteroseksualitas dikategorikan sebagai bagian dari indentitas seseorang, yaitu ciri-ciri khas dari seseorang seperti nama, umur, jenis kelamin termasuk orientasi seksual (heteroseksual, biseksual, homoseksual) dan hal ini perlu dibedakan dengan perilaku, karena identitas diri bersifat netral dan perlu diterima sebagaimana adanya, tetapi perilaku dapat bersifat positif, negatif, netral, dan lain-lain. ${ }^{36}$

\section{Homoseksualitas dalam Pandangan Iman Kristen}

Jika diamati dengan saksama, sebenarnya Alkitab tidak pernah membicarakan tentang homoseksualitas secara terinci. Memang ada beberapa bagian yang dipandang sebagai bahasan Alkitab mengenai sikap yang harus ditumbuhkan dalam menghadapi homoseksualitas, namun hal itu ditempatkan dalam konteks tertentu; sehingga sulit bagi pembaca Alkitab untuk menemukan bagian dari Alkitab yang mau berbicara tentang homoseksualitas secara utuh dan dalam keterbatasan ini penulis akan menyajikan pandangan Alkitab terhadap homoseksualitas.

\footnotetext{
33 Ibid., 100.

${ }^{34}$ Herant A Katchadourian, Instructor's Edition: Fundamental of Human Sexuality, fifth edit. (Holt: Rinehart \& Winston Inc., 1989), 381.

35 Lukas Mangindaan, “Seksualitas Yang Ditabukan: Tantangan Keberagaman,” accessed July 1, 2020,

https://nasional.kompas.com/read/2008/11/11/13081144/Homoseksual.Bukan.Penyimpangan.Seksual. 36 Ibid.
} 
Umumnya orang mengatakan bahwa penolakan praktik homoseksual itu sudah terjadi di jaman Perjanjian Lama, yaitu mengenai kisah Lot di Sodom (sebagai catatan, dari kata Sodom inilah muncul istilah sodomite (pelaku sodomi), yaitu istilah resmi yang dikenakan pada seseorang yang melibatkan diri dalam perilaku homoseksual), ${ }^{37}$ namun pendapat ini dirasa kurang kuat; karena dalam penelitian Alkitab tidak pernah satu pun pernyataan dalam Kejadian 19 menyebutkan bahwa penghuni kota Sodom adalah para homoseksual. Kejahatan yang terjadi dalam peristiwa Sodom bukanlah tertuju pada praktik homoseksual, melainkan keinginan para penduduk untuk memaksa 'malaikat Allah' untuk melayani dan memuaskan mereka, dan ini melanggar hukum kekudusan Allah. ${ }^{38}$ Justru yang seharusnya mendapat perhatian serius ketika berbicara tentang homoseksualitas adalah ungkapan hukum Musa yang ditulis dalam Imamat 20:13; yang secara eksplisit melarang seorang laki-laki untuk mengadakan hubungan seksual dengan sesama laki-laki. ${ }^{39} \mathrm{Hal}$ ini menjadi sebuah larangan karena berkaitan erat dengan hukum perkawinan yang telah dinyatakan oleh Allah kepada manusia, ketika manusia diciptakan untuk pertamakalinya.

Dalam Kejadian 1 dan 2 digambarkan bahwa setelah Allah menciptakan manusia dengan dua jenis kelamin berbeda (laki-laki dan perempuan), Allah memberikan pengesahan bagi manusia untuk melakukan hubungan seksual dalam satu lembaga perkawinan; dan Allah mengatakan bahwa laki-laki dan perempuan telah disatukan dalam satu hubungan yang setara dan seimbang, sehingga laki-laki hanya bisa melakukan hubungan seksual dengan perempuan (bahkan dengan binatang pun, tidak boleh). Jika demikian, perkawinan merupakan hubungan yang dilegalisasi oleh Allah untuk memersatukan 'hanya' antara laki-laki dan perempuan. Berdasarkan ini, maka Imamat 20:13 menegaskan bahwa hubungan sesama jenis adalah hubungan yang dilarang oleh Allah, apalagi jika dilegalkan dalam perkawinan.

Dalam Perjanjian Baru, nada yang didengungkan agak berbeda dengan Perjanjian Lama. Dalam 1 Korintus 6:9 dimuat istilah malakoi dan arsenokoitai, yang oleh Lembaga Alkitab Indonesia (LAI) diterjemahkan dengan istilah 'banci' dan 'pemburit'. Namun apakah kedua istilah ini merupakan larangan langsung mengenai praktik homoseksual? Istilah malakoi, oleh beberapa terjemahan diartikan secara berbeda-beda, BarclayNewman Greek Dictionari menerjemahkan dengan istilah homosexual pervert; King James Version dengan kata effeminate; New Revised Standard Version dengan frasa male prostitutes; New International Version dengan frasa male prostitutes; The New Jerusalem

${ }^{37}$ Frank Worthen, Mematahkan Belenggu LGBT (Malang: Gandum Mas, 2016), 35.

${ }^{38}$ Stanley J. Grenz, Sexual Ethics: An Evangelical Perspective (Kentucky: Westminster John Knox Press, 1990), 228.

39 Worthen, Mematahkan Belenggu LGBT, 36. 
Bible dengan frasa self-indulgent; dan LAI (bahasa Jawa) menerjemahkannya dengan istilah dadi gemblak (laki-laki simpanan warok). ${ }^{40}$

Hampir semua terjemahan di atas, menerjemahkan malakoi sebagai kata keterangan tentang 'apa yang dikerjakan' (kecuali KJV), bukan orangnya, dan ini menjadi masalah. TB-LAI menerjemahkan kata malakoi dengan istilah 'banci', padahal dalam Kamus Besar bahasa Indonesia (KBBI) istilah 'banci' diartikan dengan: bersifat laki-laki dan perempuan; laki-laki yang bertingkah laku dan berpakaian seperti perempuan, dan wadam (wanita - adam) atau waria (wanita - pria). Dengan kata lain, KBBI lebih mengartikan istilah 'banci' pada orangnya. Sedangkan istilah 'banci' dalam Alkitab berbeda arti KBBI, karena Alkitab menyoroti kata malakoi dalam pengertian tentang tindakan seseorang dalam melacurkan dirinya, baik kepada perempuan (menjadi gigolo) maupun kepada laki-laki (homoseksual). Orang yang melacurkan diri inilah yang dikatakan tidak mendapat bagian dalam Kerajaan Allah (sesuai dengan konteks yang ada dalam 1 Korintus 6).

Hal senada juga harus dikenakan pada istilah arsenokoitai, yang diterjemahkan LAI dengan 'pemburit'. Arsenokoitai adalah kata Yunani yang terbentuk dari kata arsen (lakilaki) dan koite yang (ranjang atau eufiminisme dari persetubuhan/sexual intercourse). James Swanson (DBL Greek) mengatakan kata arsenokoitai berarti: male homosexual, one who takes the active male role in homosexual intercourse, specifically interpreted as male homosexual paedophilia, sodomites, perverts, practicing homosexuals, homosexual. ${ }^{41}$ Istilah asenokoitai pun dikenakan oleh Paulus sesuai dengan konteks 1 Korintus 6, yaitu tentang perzinahan dan pelacuran. Dengan demikian dapat dikatakan bahwa perbincangan mengenai homoseksualitas dalam Alkitab bukan mengarahkan perhatian para pembaca kepada siapa pelaku dari tindakan homoseksualitas itu, melainkan menekankan tentang tindakan homoseksual yang tidak diperkenankan oleh Allah; karena Allah telah menciptakan manusia dalam kekudusan yang didasarkan atas seksnya (jenis kelamin). Apa pun alasan yang dikemukakan oleh berbagai kelompok yang menyatakan diri sebagai pembela hak kaum homoseksual, namun jika diperhadapkan pada nilai-nilai yang dibangun oleh Alkitab, jelas tindakan homoseksual tidak dapat dibenarkan karena melanggar kekudusan yang telah Allah letakkan dalam nilai-nilai seksualnya. Jadi jelas di sini, bahwa Alkitab melarang praktik homoseksual dengan sangat tegas dan jelas, termasuk kecenderungan hati.

Secara garis besar homoseksual digolongkan menjadi tiga, yaitu pertama, Homoseksual bawaan, yaitu keadaan yang dialami oleh laki-laki atau perempuan sejak

40 Bdk. Johannes P. Louw and Eugene Albert Nida, Greek-English Lexicon of the New Testament: Based on Semantic Domains (New York: United Bible Societies, 1996), 771-772., yang mengartikan kata malakoi dengan: the passive male partner in homosexual intercourse.

${ }^{41}$ James Swanson, Dictionary of Biblical Languages with Semantic Domains: Greek (New Testament) (Oak Harbor: Logos Research Systems, Inc., 1997). 
lahir yang membawa mereka pada kecenderungan homoseksual. Biasanya ini timbul akibat cedera otak yang dialami sebelum atau selama kelahiran. Kedua, Homoseksual Psikis, yang muncul akibat suatu perkembangan psikis yang terganggu, entah itu pada masa proses pendidikan atau akibat dari pengalaman-pengalaman khusus yang mengganggu kejiwaannya. Ketiga, Homoseksual Kondisional, yang dialami oleh orangorang yang heteroseksual, tetapi karena suatu keadaan yang 'memaksa' mereka untuk melakukan praktik homoseksual (atau bisa juga karena ingin mencari sensasi seksual di luar kebiasaan). ${ }^{42}$ Jika ketiga jenis homoseksual di atas sampai pada tataran praktik, maka Alkitab menegaskan bahwa tindakan itu tidak bisa dibenarkan. Oleh karena itu setiap kecenderungan hati yang akan membawa seseorang pada praktik homoseksual harus dikendalikan sedemikian rupa agar tidak diwujudkan dalam sebuah tindakan. Pengendalian kecenderungan tersebut senantiasa didasarkan atas kesadaran bahwa manusia telah diciptakan oleh Allah dengan jenis kelamin yang berbeda. Untuk menjaga kekudusan hidup manusia yang mau menjalani hidup bersama, maka jenis kelamin yang berbeda itu yang harus disatukan karena ini yang menentukan kekudusan yang telah Allah berikan kepada manusia. Jika manusia menyatukan jenis kelamin yang sama, maka sesungguhnya hal ini sudah melanggar hukum kekudusan Allah, sehingga manusia tidak mungkin dapat hidup di dalam kekudusan Allah.

\section{Sikap Etis Kristiani Terhadap Pelaku Homoseksual}

Di atas telah disajikan berbagai pandangan yang mengatakan bahwa homoseksualitas tidak dapat dipahami lagi sebagai bentuk penyimpangan orientasi seksual, melainkan harus dipahami sebagai bagian dari identitas diri. Namun hal ini bukan berarti bahwa tindakan dan perilaku homoseksual bisa dibenarkan. Praktik homoseksual tetaplah menjadi praktik yang tidak dapat dibenarkan, tetapi terhadap pelaku homoseksual sikap yang harus dikembangkan adalah bukan menolak namun menerima mereka dalam kehidupan bersama di masyarakat. Seringkali yang menjadi permasalahan dalam masalah homoseksualitas ini adalah pandangan gereja-gereja yang menolak keras terhadap keberadaan kaum homoseksual. Hal ini telah menimbulkan berbagai reaksi dari kaum homoseksual, karea dalam kenyataan saat ini banyak kaum homoseks menjadi anggota gereja. Sikap gereja yang tidak mau menerima mereka sesungguhnya sangat mengganggu kehidupan pribadi mereka, sehingga mereka memutuskan untuk tidak bergabung lagi dengan gereja. Mereka merasa ditolak karena gereja tidak pernah memberi tempat untuk kaum homoseksual dalam aktivitas pelayanan dalam komunitas. ${ }^{43}$ Bahkan cara pandang gereja yang seperti ini tidak jarang menuntun orang tua untuk menolak keberadaan anakanak yang coming out sebagai kaum homoseks. Akibatnya anak-anak tersebut tidak diakui sebagai bagian dari keluarga, terbuang dan tidak jarang berujung pada depresi dan bunuh

\footnotetext{
${ }^{42}$ Grenz, Sexual Ethics: An Evangelical Perspective, 224-227.

${ }^{43}$ Agung Gunawan, "Pendampingan Pastoral Bagi Kaum Lesbian, Gay, Bisexual Dan Transgender," Jurnal Theologi Aletheia 18, no. 11 (2016): 1-13.
} 
diri. Ajaran gereja yang menolak dan menafikan kaum homoseksual pada akhirnya memengaruhi komunitas, sehingga dengan tega mengucilkan kaum homoseks dari kehidupan bersama di gereja. Disinilah muncul pertanyaan berkenaan dengan sikap gereja dalam menyikapi fenomena homoseksual.

Harus diakui bahwa dewasa ini, khususnya di kalangan Kristen, jumlah kaum homoseksual semakin banyak, dan hal ini seyogyanya mendorong gereja untuk bertanggung jawab dalam menghadapi isu ini dengan lebih bijak, jujur, terbuka dan sensitive. ${ }^{44}$ Untuk itu gereja harus kembali kepada tugas utama mereka untuk menerima setiap mereka yang disisihkan dan dimarginalisasikan oleh masyarakat dengan mengembangkan sikap sebagai berikut: Pertama, gereja harus menerima setiap kaum homoseksual (Kristen) sebagai saudara dengan tulus tanpa didasarkan pada praduga negatif berdasarkan orientasi seksual mereka. Kedua, gereja harus mengambil tindakan yang penuh tanggung jawab untuk menghadapi sikap anti-homoseksual dengan cara merumuskan sikap yang mendukung dan mengubah pandangan negatif terhadap kaum homoseksual.

Ketiga, panggilan keadilan sosial dalam Kekristenan hendaknya mendorong gereja untuk menyikapi dan melawan sikap diskriminatif terhadap kaum homoseksual. Akibat sikap diskriminatif ini kaum homoseksual seringkali menerima pengingkaran terhadap hak-hak mereka berupa: pekerjaan perumahan akomodasi publik, pendidikan, bahkan dalam menikmati kemerdekaan mereka sebagai warga negara di wilayahnya. Keempat, gereja dipanggil untuk meningkatkan upaya-upaya berteologi dan beretika dengan penuh tanggung jawab. Gereja harus terbuka terhadap pandangan-pandangan yang penting dari para teolog (termasuk teolog feminis dan yang dipandang sebagai teolog sekuler), agar gereja selalu mengingat berbagai macam kondisi (termasuk kondisi seksual) yang sangat memengaruhi dan mewarnai persepsi gereja tentang sifat dan kehadiran Allah di dunia. Prinsip-prinsip kebenaran Kristiani seyogyanya mendorong gereja berani melawan berbagai upaya pengabsolutan nilai-nilai teologis yang cenderung tidak memihak pada kehidupan, termasuk kepada kelompok-kelompok yang dimarginalkan (termasuk kaum homoseksual). Kelima, dengan menyadari bahwa mayoritas anggota gereja memiliki orientasi heteroseksual, maka hal ini menjadi keuntungan gereja ketika bergulat di dalam masalah homoseksualitas, khususnya mengenai peningkatan kemampuan mencintai manusia lain dengan lebih sungguh dan tanpa rasa takut.

Kelima butir ini menunjukkan dinamika yang dihadapi oleh gereja-gereja Kristen baik yang ada di dunia maupun di Indonesia, bahwa cepat atau lambat gereja harus berusaha untuk menerima kenyataan bahwa kaum homoseksual ada di tengah-tengah kehidupan, dan gereja mau tidak mau harus berani menerima keberadaan mereka. Secara

44 James B. Nelson, "Homosexuality and the Church: Christianity and Crisis," accessed July 1, 2020, http://www.religion-online.org/showarticle.asp?title $=430$. 
perlahan namun berkesinambungan, gereja harus terus berjuang untuk membangun teologi yang mampu menjawab tantangan dan pergumulan jaman ini. Meskipun ayat-ayat Kitab Suci dapat dipakai untuk menolak kaum homoseksual, namun gereja harus berani untuk mengambil sikap berbeda, yaitu menerima para kaum homoseksual tersebut sebagai seorang manusia sejati, sebagaimana penerimaan gereja terhadap manusia pada umumnya.

Dengan bertolak dari uraian di atas, maka sikap etis - Kristiani yang harus dibangun adalah menciptakan sebuah bentuk teologi yang berusaha menerima setiap pribadi mereka yang terjerat dalam tindak homoseksual tanpa harus berkompromi dengan praktik homoseksual. Bentuk teologi yang ditawarkan adalah 'teologi penerimaan, yang menjadi sebuah pesan etis dan moral dari Injil, yaitu setiap orang harus mampu untuk menerima dirinya sendiri. ${ }^{45}$ Penerimaan diri ini hanya bisa terjadi jika ketika seseorang mau menerima keberadaan orang lain sama seperti Tuhan yang selalu menerima manusia dengan segala keberadaannya. Dalam hal penerimaan inilah yang belum dirasakan oleh kaum homoseksual. Di rumah mereka ditolak oleh keluarga, di gereja mereka dipandang sebagai orang berdosa, di masyarakat mereka dipandang sebagai orang sakit karena memiliki penyimpangan seksual, secara hukum mereka dipandang sebagai kaum kriminal, dan di segala lini kehidupan mereka menjadi manusia terbuang. Dalam posisi ini gereja harus melayani kaum homoseksual yang disisihkan dan dibuang. Teologi penerimaan mengumandangkan bahwa Allah adalah "Pencinta Kosmik" yang tidak pernah berhenti ataupun gagal dalam menunjukkan tindakanNya sebagai wujud kasih. Teologi penerimaan ini menjadi sebuah jalan utama yang diberitakan dan dipraktikkan melalui hidup dan karya Yesus Kristus. Kemampuan seperti inilah yang harus ditumbuhkembangkan gereja untuk memanjangkan dan meningkatkan kapasitas gereja dalam mencintai tanpa syarat seperti Allah mencintai manusia. Gereja benar-benar sedang ditantang untuk bersikap dan menumbuhkan teologi penerimaan melalui kehadiran kaum homoseks ini.

\section{Kesimpulan}

Sikap etis - Kristiani terhadap pelaku homoseksualitas adalah sama seperti yang dikembangkan oleh PGI , yaitu tidak menolak keberadaan kaum homoseksual. Yang harus ditolak adalah praktik homoseksual yang terjadi, tetapi bagi para pelaku homoseksual, gereja harus berani menerima mereka seperti apa adanya mereka dengan terus membimbing mereka untuk kembali pada kehidupan yang memang diharapkan oleh Allah, yaitu hidup kudus dalam kekudusan seksual. Hal ini senada dengan pertanyaan Yesus tentang, "Siapakah sesamamu?" seperti yang pernah diungkapkan-Nya di dalam

45 Helen Diana Subekti, Endah Triwijati, and Teguh Wijaya Mulya, "Penerimaan Dan Penolakan Homoseksual Berbasis Pengalaman Pribadi Teologi Kekristenan Dari Sisi Pendetaan Agama Kristen," KELUWIH: Jurnal Sosial dan Humaniora 1, no. 1 (2020): 30-40. 
cerita "Orang Samaria yang Baik Hati". "Sesama kita” adalah semua orang di muka bumi ini, termasuk mereka yang tergolong dalam kelompok homoseksual. Mereka juga adalah ciptaan Tuhan, yang 'segambar dan serupa' dengan Tuhan, karena itu apa pun yang terjadi keberadaan mereka tetap menjadi bagian dari keberadaan manusia yang hidup di alam ciptaan Tuhan.

\section{Referensi}

Adeney-Risakotta, Farsijana. "Menguak Teologi Feminis Asia." Gema Teologika 55 (1995): 1-23.

Anggito, Albi, and Johan Setiawan. Metodologi Penelitian Kualitatif. Sukabumi: CV Jejak, 2018.

Drakeford, John W. A Christian View of Homosexuality. Tennessee: Broadman Press, 1977.

Gardner, E.C. Justice and Christian Ethics. Cambridge: Cambridge University Press, 1995.

Grenz, Stanley J. Sexual Ethics: An Evangelical Perspective. Kentucky: Westminster John Knox Press, 1990.

Gunawan, Agung. "Pendampingan Pastoral Bagi Kaum Lesbian, Gay, Bisexual Dan Transgender." Jurnal Theologi Aletheia 18, no. 11 (2016): 1-13.

Halawa, Junius. "Seks Menurut Alkitab Sebagai Kontribusi Bagi Pengajaran Gereja Masa Kini." Scripta: Jurnal Teologi dan Pelayanan Kontekstual 8, no. 2 (2020): 164-180.

Hartmann, Uwe. "Sigmund Freud and His Impact on Our Understanding of Male Sexual Dysfunction." Journal of Sexual Medicine 6, no. 8 (2009): 2332-2339.

Katchadourian, Herant A. Instructor's Edition: Fundamental of Human Sexuality. Fifth edit. Holt: Rinehart \& Winston Inc., 1989.

Kinsey, Alfred. Sexual Behaviour in the Human Female. Philadelphia: W. B. Saunders Co., 1953.

Lahaye, Tim Beverly. Kehidupan Seks Dalam Pernikahan. Bandung: Kalam Hidup dan ANDRI, 1992.

LeVay, Simon. In Queer Science. Cambridge: MIT Press, 1996.

Louw, Johannes P., and Eugene Albert Nida. Greek-English Lexicon of the New Testament: Based on Semantic Domains. New York: United Bible Societies, 1996.

MacCulloch, Malcolm. "Biological Aspects of Homosexuality." Journal of Medical Ethics (1980).

Mangindaan, Lukas. "Seksualitas Yang Ditabukan: Tantangan Keberagaman.” Accessed July $1,2020$.

https://nasional.kompas.com/read/2008/11/11/13081144/Homoseksual.Buka n.Penyimpangan.Seksual.

Manshur, Fadlil Munawwar. "Teori Dialogisme Bakhtin Dan Konsep-Konsep Metodologisnya." SASDAYA: Gadjah Mada Journal of Humanities 1, no. 2 (2017).

Monding, Yushiko D. "Tinjauan Teologis Tentang Pendidikan Seks Dari Perspektif Pendidikan Kristiani Transformatif." Pengarah: Jurnal Teologi Kristen 2, no. 2 (2020): 173-182.

Nelson, James B. "Homosexuality and the Church: Christianity and Crisis." Accessed July 1, 2020. http://www.religion-online.org/showarticle.asp?title=430. 
“NN.” "Facts About Homosexuality and Mental Health.” Accessed June 25, 2020. http://psychology.ucdavis.edu/rainbow/html/ facts_mental_health.htm. . "UN Passes LGBT Rights Resolution.” Accessed July 1, 2020. http://en.wikinews.org/wiki/UN_passes_LGBT_rights_resolution?utm_source=fe edburner\&um medium $=$ feed\&utm_campaign=Feed $\% 3 \mathrm{~A}+$ WikinewsLatestNews+\%28Wikinews + Latest+News\%29.

Oetomo, Dede. Memberi Suara Pada Yang Bisu. Yogyakarta: Pustaka Marwa, 2003.

Onghokham. "Kekuasaan Dan Seksualitas: Lintas Sejarah Pra Dan Masa Kolonial." Prisma 20, no. 7 (1991): 15-23.

Panjaitan, Firman. "Kekerasan Terhadap Istri Dalam Lingkup Domestik (Suatu Tinjauan Etis Kristiani Tentang Kekerasan Terhadap Keluarga).” Fidei: Jurnal Teologi Sistematika dan Praktika 1, no. 1 (2018): 42-67.

PGI. "Pengantar Penyataan Sikap PGI.” No.: 360/PGI-XVI/2016. Jakarta, June 17, 2016.

Rakhmahappin, Yogestri, and Adhyatman Prabowo. "Kecemasan Sosial Kaum Homoseksual Gay Dan Lesbian.” Jurnal Ilmiah Psikologi terapan 02, no. 02 (2014): 199-213.

Satinover, Jeffrey. Homosexuality and the Politics of Truth. MI: Baker Books, 1996.

Subekti, Helen Diana, Endah Triwijati, and Teguh Wijaya Mulya. "Penerimaan Dan Penolakan Homoseksual Berbasis Pengalaman Pribadi Teologi Kekristenan Dari Sisi Pendetaan Agama Kristen." KELUWIH: Jurnal Sosial dan Humaniora 1, no. 1 (2020): 30-40.

Suryakusuma, Julia I. “Konstruksi Sosial Seksualitas.” Prisma 20, no. 7 (1991).

Swanson, James. Dictionary of Biblical Languages with Semantic Domains: Greek (New Testament). Oak Harbor: Logos Research Systems, Inc., 1997.

Tu'u, Tulus. Etika Dan Pendidikan Seksual. Bandung: Kalam Hidup, n.d.

Weeks, Jeffrey. “Question of Identity.” In The Cultural Construction of Sexuality, edited by Pat Caplan. New York: Tavistock Publication, 1987.

Westermann, Claus. Genesis 1-11: A Commentary. Minneapolis: London and Ausburg Publishing House, 1984.

Worthen, Frank. Mematahkan Belenggu LGBT. Malang: Gandum Mas, 2016. 